\title{
Saliva and Oral Diseases
}

\author{
Emanuela Martina ${ }^{+}\left(\mathbb{D}\right.$, Anna Campanati ${ }^{*},{ }^{\dagger}$, Federico Diotallevi and Annamaria Offidani \\ Dermatology Clinic, Department of Clinical and Molecular Sciences, Polytechnic Marche University, \\ via Conca 71, 60126 Ancona, Italy; ema.martina@gmail.com (E.M.); federico.diotallevi@hotmail.it (F.D.); \\ a.offidani@ospedaliriuniti.marche.it (A.O.) \\ * Correspondence: anna.campanati@gmail.com; Tel.: +39-0715963433 \\ + These authors contributed equally to the manuscript.
}

Received: 29 December 2019; Accepted: 3 February 2020; Published: 8 February 2020

\begin{abstract}
Saliva is a fascinating biological fluid which has all the features of a perfect diagnostic tool. In fact, its collection is rapid, simple, and noninvasive. Thanks to several transport mechanisms and its intimate contact with crevicular fluid, saliva contains hundreds of proteins deriving from plasma. Advances in analytical techniques have opened a new era-called "salivaomics"—that investigates the salivary proteome, transcriptome, microRNAs, metabolome, and microbiome. In recent years, researchers have tried to find salivary biomarkers for oral and systemic diseases with various protocols and technologies. The review aspires to provide an overall perspective of salivary biomarkers concerning oral diseases such as lichen planus, oral cancer, blistering diseases, and psoriasis. Saliva has proved to be a promising substrate for the early detection of oral diseases and the evaluation of therapeutic response. However, the wide variation in sampling, processing, and measuring of salivary elements still represents a limit for the application in clinical practice.
\end{abstract}

Keywords: biomarkers; saliva; oral cancer; oral lichen planus; psoriasis; oral diseases

\section{Introduction}

Saliva is a biological fluid secreted by major and minor salivary glands. The major salivary glands are the parotid, submandibular, and sublingual glands. Minor salivary glands are widely disseminated throughout the entire oral cavity. Saliva provides lubrication; facilitates mastication, digestion, and taste; it has antimicrobial properties; and serves as buffer for acidic food. Moreover, saliva inhibits the demineralization of teeth and protects from caries [1]. The physiological secretion generates $0.75-1.5 \mathrm{~L}$ per day, with a decrease during the night [2]. Saliva contains $99 \%$ water and proteins for the remaining 1\% (mucins, enzymes, immunoglobulins), electrolytes, lipids, and inorganic substances [3].

There are many advantages to employing saliva as a substrate for diagnostic analysis. Its sampling is fast, inexpensive, non-invasive, and well tolerated by children and people with disabilities; moreover, it is a safe procedure for healthcare providers [4]. Many serum substances enter saliva through passive diffusion, active transport, or extracellular ultrafiltration [5]. Obviously, compared with blood, levels of several analytes are lower, which was an obstacle until a few years ago [6]. Nowadays, highly sensitive molecular methods are available and can be used in the detection of many elements in saliva, despite their dimensions and concentrations [7].

In recent decades, enormous progress has been made in early diagnosis and screening for many diseases, especially for neoplastic conditions. However, some of these methods are invasive or expensive, and for certain conditions, accurate tests are still not available. This is the case for oral cancer, the sixth most common cancer worldwide, frequently diagnosed at an advanced stage with a 5 year survival rate of $50 \%$ [8].

In accordance with Biomarkers Definitions Working Group 2011, a biomarker is a characteristic that can be objectively measured and evaluated as indicator of normal biological or pathogenic 
processes, or as an indicator of pharmacologic response to therapeutic interventions [9]. The detection of salivary biomarkers and their use in clinical practice in the near future is one of the most ambitious aims of contemporary researchers.

\section{Materials and Methods}

The review was conducted in accordance with the PRISMA (Preferred Reporting Items for Systematic Reviews and Meta-Analyses) checklist. A search in the PubMed database was carried out using the keywords "saliva", "salivary", "biomarkers", "oral diseases", "oral lichen planus", "oral cancer", and associations between terms. We selected only articles written in English. The papers were selected first by analyzing titles and abstracts, in order to choose a correct match with our topic; full-text articles were then studied and included in the revision.

\section{Sampling and Processing Techniques}

Many factors can alter the composition and total amount of saliva. The time of day, hydration, body position, drugs intake, smoking, psychological stimuli, food assumption, and other factors related to systemic conditions can change the characteristics of saliva in a single subject [10]. A sample of saliva can be collected at rest or after stimulation. This procedure consists of offering a gum or swab to chew, or specific taste stimuli such as citric acid [11]. The stimulation changes not only the volume, but also the composition of saliva; it has been demonstrated that parasympathetic stimulation produces a high flow rate, but sympathetic stimulation produces a small flow richer in proteins and peptides [12]. Consequently, proteome profile and proportion are changeable as a reaction to neural activation [13].

As regards clinical trials, saliva is usually collected at rest ("unstimulated saliva") after at least $1 \mathrm{~h}$ of fasting, without drinking or smoking; the patient must be comfortably seated, avoid oro-facial movements for $5 \mathrm{~min}$, and, just before the sampling, has to rinse their mouth with deionized water [11].

Saliva specimens can be collected from whole saliva or from a single gland (for example, the parotid gland). This procedure, which uses a different method, can be uncomfortable for patients and therefore is rarely used [14]. It should be specified that whole saliva has a higher proportion of non-salivary materials such as food debris, bacteria, desquamated epithelial cells, and leukocytes [15].

The gold standard method is to drain saliva using special devices (Salivette ${ }^{\circledR}$, Sarstedt, Nümbrecht, Germany; Quantisal ${ }^{\circledR}$, Immunalysis, Pomona, CA, USA; Orapette ${ }^{\circledR}$, Trinity Biotech, Dublin, Ireland and SCS ${ }^{\circledR}$ Greiner Bio-One, Kremsmünster, Austria) [16].

Controversies are evident in the literature regarding centrifugation and speed, addition of PIC (protease inhibitor cocktail), and storage temperature. Most authors recommended the use of a protease inhibitor mixture in order to stabilize the substrate; moreover, the samples collected must be immediately stored in ice containers and, after processing, stored at $-80^{\circ} \mathrm{C}$ [17]. All these steps are necessary for bacterial growth inhibition and the minimal impairment of salivary proteins.

\section{4. "Salivaomics"}

The term "salivaomics" was coined in 2008 to emphasize the various "omics" found in saliva: genome, transcriptome, proteome, metabolome, and microbiome [18]. Salivaomics has been widely studied in recent years thanks to the advent of more advanced analytical techniques. Nearly $70 \%$ of the genome in saliva is human; the remaining 30\% belongs to the oral microbiota [19]. The DNA contained in saliva is approximately $24 \mu \mathrm{g}$ (range $0.2-52 \mu \mathrm{g}$ ), which is almost 10 times lower than in blood, but genotyping techniques require as little as $5 \mathrm{ng} / \mathrm{mL}$ of DNA to work effectively [20]. Polymerase chain reaction (PCR) and sequencing arrays can be applied to saliva samples. The analysis of salivary DNA aims especially to detect aberrant DNA methylation, which is the first epigenetic mark of neoplastic alterations [21]. 


\subsection{Transcriptomes}

mRNA and microRNA secreted from cells can be easily detected in saliva. Reverse transcriptase polymerase chain reaction and microarray are the most commonly used analyses. Zhang et al. first developed a technique to permit stabilization and to process salivary RNA [22]. The great potential of transcriptome study in the early detection of cancer and other diseases has been reported [23-25]. More recently, noncoding RNAs (ncRNAs) or microRNAs (miRNA) have been the subject of many studies because of their role in oncogenesis and their great stability in biological fluids, including saliva [26]. MicroRNAs are encoded by genes but are not translated into proteins; it is now generally accepted that these small nucleotides are involved in cell differentiation, proliferation, and survival. Moreover, many studies have already demonstrated the dysregulation of miRNAs in cancer tissues [27,28]. Surprisingly, salivary microRNAs are more stable than mRNAs, which makes this biological fluid a suitable substrate for transcriptome analysis.

\subsection{Metabolome}

The endogenous metabolites are nucleic acids, vitamins, lipids, organic acids, carbohydrates, thiols, and amino acids. The study of the salivary metabolome can provide an overview of the general health status or modification during systemic diseases [29]. In 2010, Sugimoto et al. first used salivary metabolome analysis with capillary electrophoresis and mass spectrometry to detect differences between healthy controls and patients with solid cancer [30]. The authors identified three metabolites that were oral-cancer-specific and eight metabolites that were pancreatic-cancer-specific. Nuclear magnetic resonance (NMR) spectroscopy can detect and measure metabolites in a solution with minimal sample preparation. This quantitative technique is based on the magnetic properties of atomic nuclei [31]. Each compound has a characteristic resonance frequency that makes it easy to distinguish. Moreover, the area under a signal peak is proportional to the concentration of the metabolite [32]. Liquid chromatography-mass spectrometry (LC-MS) is considered the gold standard in metabolomics. In fact, it is able to analyze an enormous range of analytes with a greater sensitivity than NMR [33]. This technique provides very high chromatographic resolution and its results are easily interpretable using libraries of molecular fragmentation patterns [34].

\subsection{Proteome}

The term "proteome" encompasses all proteins in the oral cavity. Saliva contains more than 2000 proteins with a multitude of biological activities [35] and one quarter of salivary proteins are detectable in plasma. The greatest obstacle to salivary proteome analysis is its rapid degradation, which occurs just minutes after sample collection. For this reason, the majority of researchers combine the saliva with protease inhibitor cocktails (PIC) before storage and analysis, as suggested by Xiao et al. [36]. Proteomics takes advantage of NMR spectroscopy and gas and liquid chromatography-mass spectrometry (GC-MS and LC-MS), described above. In this research field, two-dimensional polyacrylamide gel electrophoresis (2D-PAGE) and capillary electrophoresis with electrochemical detection are essential tools [37]. 2D-PAGE, which precedes the advent of 2D-difference gel electrophoresis (2D-DIGE), fractionates proteins on the basis of their isoelectric points in the first dimension and apparent molecular weight in the second [38]. An amphoteric carrier or an ampholyte is added to a gel and subjected to electrophoresis under a continuously regulated temperature. The acrylamide gel is placed in a glass tube and proteins are separated via an isoelectric gradient; it is easy to understand why this method is poorly accurate with multiple samples. 2D-DIGE dramatically improved 2D-PAGE thanks to the possibility of labeling each sample with distinct fluorescent dyes and then reading them using a laser scanner. Immunoassay is one of the most commonly used analytical techniques to detect the expression of an antibody or an antigen in a test sample. Enzyme-linked immunosorbent assay (ELISA) has been used for a variety of applications including diagnostic tools and quality controls [39]. The four basic setups are direct, indirect, sandwich, and competitive ELISAs. Direct ELISA is the 
simplest format, requiring an antigen and an enzyme-conjugated antibody specific to the antigen [40]. The ELISA method is a sensitive and specific test that rapidly produces results and for these advantages has found a wide field of applications in clinical practice (e.g., in viral serology tests).

\subsection{Microbiome}

The study of microbiota has probably been the largest topic in scientific literature in recent years. In fact, next-generation sequencing has allowed the identification of thousands of phylotypes of microorganism throughout the entire human body, and research is ongoing. About 19,000 microorganisms have been identified in saliva [41]. Oral dysbiosis can lead to periodontal disease [42], caries [43], and some evidence exists supporting an association with cancer and systemic diseases [44,45]. Nowadays, molecular biology methods such as 16S ribosomal RNA (rRNA) gene sequencing, polymerase chain reaction (PCR), and other related PCR-based methods are very popular thanks to their high sensitivity and reproducibility. However, these techniques are no longer employed in routine diagnostics due to their costs. Alternative approaches include electromigration techniques (two-dimensional gel electrophoresis, capillary zone electrophoresis) and MS methods, such as matrix-assisted laser desorption ionization time-of-flight mode (MALDI-TOF MS). MALDI-TOF MS is a fast and accurate method based on the ionization of intact microorganism cells with short laser pulses and the subsequent acceleration of the particles in a vacuum by way of an electric field. Each microorganism has a specific spectrum profile [46].

Histopathology, in some cases with direct immunofluorescence, remains the gold standard for the diagnosis of oral disease. In fact, it is often necessary to perform a biopsy to confirm the diagnosis of bullous diseases (together with DIF) [47], Sjögren's syndrome [48], and for all lesions suspected for malignancy [49].

\section{Fields of Application}

In this article, we have summarized the latest findings on the use of saliva as a diagnostic tool in oral inflammatory diseases. In particular, we chose the most epidemiologically relevant conditions or where the oral cavity is a typical location of a systemic disease. In fact, mouth disorders can often precede the onset of systemic symptoms (e.g., in bullous pemphigus), and early diagnosis of oral disease can change the prognosis of these patients. In this scenario, the study of salivary biomarkers is a promising tool for early diagnosis and screening in susceptible populations (e.g., in smokers).

\subsection{Oral Lichen Planus}

Oral lichen planus (OLP) is one of the most common chronic inflammatory condition of the oral mucosa, with $0.5 \%-2 \%$ prevalence in adults and a slight predominance in women [50]. OLP affects oral mucosa symmetrically, with a predilection for oral mucosa. Clinically, it is possible to distinguish different aspects: reticular (the most prevalent form), erythematous, ulcerative or erosive, plaque-like, bullous, or papular [51,52]. The histopathology of OLP is typical, with a prominent lymphocyte infiltrate at the interface of epithelium, acanthosis, and degeneration of the basal cell layer [53]. Direct immunofluorescence (DIF) permits deposition of Immunoglobulin M as colloid bodies and C3 in granular and linear patterns in the basement membrane zone to be detected [54]. Although the exact pathogenesis of OLP is mostly unknown, it is believed that autoreactive T cells play a crucial role in the disease. Several risks/triggers factors have been described, such as stress, $\mathrm{HCV}$ and viral infections, and drugs [55]. OLP has been classified as a premalignant lesion for its risk of malignant transformation (0.04-1.74 per year) in squamous cell carcinoma (OSCC) [56]. Patients affected by OLP suffer from burning and itching sensations up to a severe pain in the erosive form; the disease has a huge negative impact on quality of life due to impairment in daily activities such as eating or oral hygiene [57]. Published articles focused on salivary biomarkers in OLP are quite recent and concern the diagnosis of OLP, but in particular the early detection of malignant transformation. 
In 2018, Sineepat et al. enrolled five OLP patients and five healthy controls using a proteomic approach on saliva with two-dimensional gel electrophoresis followed by mass spectrometry. The authors detected three proteins that showed a potential role in OLP patients (cystatin SA, chain $\mathrm{C}$ of human complement component $\mathrm{C} 3 \mathrm{c}$, and chain $\mathrm{B}$ of fibrinogen fragment $\mathrm{D}$ ) and tested with ELISA. All the analytical techniques confirmed with statistical significance that fibrinogen fragment $\mathrm{D}$ and complement component $\mathrm{C} 3 \mathrm{c}$ were increased and cystatin SA was decreased in OLP patients compared with healthy subjects [58]. Fibrinogen fragments D and C3c play a central role in inflammation, whereas cystatin SA belongs to the cystatin superfamily, a group of cysteine protease inhibitors with antimicrobial activity. In fact, fibrinogen expression and C3 deposition are typical findings in OLP using IFD [54].

A different and more complex panel of proteins was reported by another study, published in 2017 [59]. The study was conducted on 10 patients, investigating with mass spectrometry 108 proteins differentially expressed in OLP subjects in comparison to healthy controls. The first finding was the absence of proteins essential to lubrication and viscoelasticity, supporting the xerostomia symptom frequently reported by patients. The authors interestingly tried to link protein expression in saliva with histological findings in OLP, discussing the known functions of each peptide. In particular, S100A8 and S100A9 (also called MRP8 and MRP14) are calcium- and zinc-binding proteins with a role in inflammation and cytokine production via IL-17. S100A8 can also induce apoptosis via attraction to skin of $\mathrm{CD}^{+}$cells and natural killer (NK) cells [60]. Another player in the scene of T-cell proliferation and differentiation is AZGP1 (zinc-alpha-2-glycoprotein), which is an adipocytokine [61]. The study also confirmed the crucial role of oxidative stress in OLP; reactive oxygen species (ROS) induce apoptosis and dysfunction in keratinocytes and, moreover, ROS can be further produced from $\mathrm{TCD} 4^{+}$lymphocytes infiltrating in OLP in a vicious circle.

Oxidative stress in OLP was previously discussed in 2016 in a case-control study enrolling 62 patients and 30 healthy individuals [62]. The authors demonstrated significant differences between patients and the control group concerning the average concentration of total antioxidant capacity (TAC, determined using the Benzie and Strain method [26]), glutathione (GSH, measured spectrophotometrically), and thiobarbituric-acid-reactive substances (TBARS, determined using the Aust method), which are a product of lipid peroxidation [63]. In patients suffering from OLP, as expected, TAC and GSH had lower values, while TBARS was higher than in healthy controls. More interestingly, patients with an erosive form of lichen had more marked values, demonstrating severe oxidative stress and a great concordance with clinical features. These findings could support the oral or topical use of antioxidants [64].

Many authors have suggested salivary cortisol as a biomarker in OLP [65-70]. Cortisol is considered a biological marker of stress and anxiety, the variation of which can alter cytokine profiles [71]. OLP has a double connection with stress: anxiety and stressful events are considered a trigger for OLP onset but, at the same time, oral lichen itself represent a source of stress for patients. In this intricate scenario, the evaluation of salivary cortisol seems to mimic the ancestral question "Which came first, the chicken or the egg?" In fact, data from the literature are controversial, and cortisol is probably not suitable as a biomarker in OLP. As previously discussed, OLP is a T-cell-driven disease; however, it is still unclear if the inflammation is due to Th1 or Th2 expression. In fact, in OLP, there are numerous cytokines expressed both from recruited lymphocytes and from affected keratinocytes, in a mechanism of self-amplification [72]. The evaluation of specific interleukin in saliva is certainly a good trace to detect biomarkers in OLP and, moreover, to design tailored therapies. Nowadays, more consistent results concern IL- 6 and IL-8. Interleukin- 6 is involved in B- and T-cell differentiation and is able to inactivate p53 with tumor progression of some cancers [73]. Mozaffari et al. revealed in a meta-analysis that IL-6 levels in saliva and serum of OLP patients were significantly higher than in healthy controls, with higher values in saliva than in serum [74]. For this reason, saliva seemed to be more useful than serum for the detection of IL-6. Interleukin- 8 is an important mediator of host response to injury and inflammation; it can activate neutrophils, basophils, and T cells [75]. The group of Mozaffari conducted 
a meta-analysis on this topic [76]. The most interesting finding was that IL-8 plays a key role in the transformation from reticular to erosive form of lichen, probably due to the loss of efficacy in the repairing mechanisms of keratinocytes [77]. IL-8 also revealed a potential application in therapeutic monitoring, as demonstrated via its decrease in saliva after dexamethasone administration [78].

\subsection{Oral Cancer}

Oral cancer is the sixth most common cancer worldwide [79] with a higher incidence in India, because of the chewing of areca nut/betel quid [80]. The mortality rate after 5 years from diagnosis is still 50\% [79]. Well-known risk factors include tobacco consumption, alcohol abuse, and human papilloma virus infections [81]. The onset of an oral cancer is frequently asymptomatic, but most oral carcinomas develop from premalignant conditions such as leukoplakia and oral lichen planus $[82,83]$. Nowadays, the gold standard for diagnosis is tissue biopsy, an invasive technique that requires specific training and creates public health costs [84]. It is therefore easy to understand the need for an early detection method for pre-cancer and cancer by validating salivary biomarkers. Above, we discussed the great diagnostic potential of miRNA both in saliva and serum. In 2018, a well-designed study enrolled 30 patients with OLP, 15 patients with OSCC and 15 healthy donors [85]. Saliva samples were analyzed by quantitative RT-PCR for miR-21, miR-125a, miR31, and miR200a. Results showed that miRNA-21 and -125a were, respectively, higher and lower in OSCC patients and in OLP with dysplasia compared to healthy controls with statistical significance. miR-21 has been widely studied in oral, head, and neck cancer and has been postulated that it might have a role in inhibition of tumor suppression and apoptosis [86]. In contrast, miR-125a may act as a tumor suppressor, downregulating target oncogens [87]. Based on these data, the authors suggested a negative prognostic role of decreased salivary miR-125a levels in association with increased salivary miR-21 levels in OLP patients. Ishikawa et al. recently suggested a metabolomics approach to distinguish OLP from OSCC [88]; the authors detected higher levels of 12 salivary metabolites in OSCC patients compared with OLP patients. More specifically, the combination of indole-3-acetate and ethanolamine phosphate showed the best statistical accuracy. The aim of Mikkonen's research was to investigate the potential of nuclear magnetic resonance (NMR) spectroscopy for detecting the salivary metabolic changes associated with head and neck squamous cell carcinoma (HNSCC). The Authors found two metabolites, fucose and 1,2-propanediol, to be significantly upregulated, whereas proline was significantly downregulated in patients affected by HNSCC. The combination of four salivary metabolites (fucose, glycine, methanol, and proline) together provided maximum discrimination among HNSCC patients and healthy controls [31]. The role of fucosylation of glycoproteins in the development of cancer has been studied in recent years [89]. Ample evidence exists to prove that in normal tissues, fucosylation levels are relatively low, but this rapidly increases during carcinogenesis [90]. Aberrant glycosylation in cancer development is also an investigation area in oral diseases; in particular, researchers have focused attention on sialic acid (N-acetyl neuraminic acid), which is an important terminal sugar in cell membrane glycoproteins and glycolipids. Previous studies have shown elevated levels of salivary sialic acid in various carcinomas, including oral pre-cancer and OC [91-93].

The fascinating study of the microbiome has a wide field of application in the oral cavity. An extensive work has just been published regarding the alterations of salivary microbial community in oropharyngeal and hypopharyngeal carcinoma patients. In fact, the microbiome is considered a potential modulator of cancer metabolism [94]. The authors found 13 phylotypes of microorganism as potential diagnostic biomarkers in oral cancer. The role of the microbiome in malignant change in the oral cavity is still controversial because of the lack of large cohort studies. Healy et al. considered the implication of risk factors such as smoking or alcohol consumption in promoting epithelial dysplasia and production of carcinogenic agents [95]. Acetaldehyde (ACH) and N-nitrosamine compounds are potential genotoxic agents that are increased in the saliva of smokers; these compounds can be produced in vitro by microbial cultures [96,97]. In vitro studies have demonstrated the leading role of Neisseria species and Candida species in $\mathrm{ACH}$ production [98,99]. However, one study revealed the 
reduction of Neisseria species in the oral cavity of smokers, with a theoretical improvement of ACH levels [100]. Current theories hypothesize that the presence of these organisms could accelerate the progression of dysplasia towards OSCC in association with predisposing factors such as diet, age, or smoking/alcohol consumption habits in a multifactorial vision.

\subsection{Blistering Diseases}

Bullous pemphigoid (BP) and pemphigus vulgaris (PV) are acquired bullous diseases affecting the mucosa and/or skin. In both diseases, autoantibodies react with adhesion cell mechanisms or with the basement layer, resulting in blistering. Blisters are intraepithelial/intraepidermal in PV, whereas in BP they are subepithelial/subepidermal [101]. The diagnosis is first clinical, then confirmed with histopathology and direct immunofluorescence (IFD). In BP, bullae involving the skin and oral lesions are rare; in contrast, PV frequently begins with oral blistering or oral lesions following cutaneous involvement. IFD reveals IgG and C3 (BP180) deposition on the basement membrane in BP, while in PV it shows intercellular IgG antibody deposition to desmoglein (Dsg) 1 and/or desmoglein 3, which are trans-membrane desmosomal proteins [102]. In recent years, the use of ELISA to detect autoantibodies in the serum of BP and PV patients has entered clinical practice for diagnosis and therapeutic monitoring [101]. Starting from this technique, some authors have proposed the use of saliva as substrate for the research of BP180 and Dsg1 and 3. In 2006, Andreadis et al. first applied ELISA in both the serum and saliva of PV and BP patients, finding a great concordance in serum and saliva levels of Dsg1 and 3, while the BP180 determination on saliva failed [103]. Similar results emerged from Ali's study [104] on Dsg1 and 3. The potential of salivary testing in PV prognosis and mucosal severity has been investigated in two studies. Hallaji et al. included 50 patients with histologically confirmed PV and performed ELISA for Dsg1 and 3 on serum and saliva samples [105]. There was statistically significant concordance between serum and salivary levels of Dsg; more interestingly, there was a significant relationship between salivary anti-Dsg1 antibody and mucosal severity. The authors explained these data with the loss of integrity in mucosa and the largest transition of antibodies in saliva. The study of De et al. perfectly reproduced this finding and the authors perfectly agreed with the explanation concerning higher Dsg1 levels in severe disease [106]. In contrast to the previously discussed research, one Italian study was designed to assess the use of a BIOCHIP approach compared with ELISA in PV [107]. In fact, the authors considered saliva an unsuitable substrate for autoantibody detection because of the discordance between techniques found when using saliva samples.

\subsection{Sjögren's Syndrome}

Sjögren's syndrome (SS) is a systemic autoimmune disease characterized by the inflammation and consecutive destruction of exocrine glands, as well as salivary and lacrimal glands, with the occurrence of a lymphoepithelial sialadenitis [108]. The majority of patients are women of menopausal age; oral manifestations are frequently present at the onset of disease, but some patients develop a systemic disease with the involvement of joints, the gastrointestinal tract, the central nervous system, and with an increased risk of lymphoma [109]. Patients suffering from SS typically complain about xerostomia and its impact on their quality of life [110]. Current research on salivary biomarkers in SS is pursuing a non-invasive diagnostic test, a therapeutic monitoring marker, and, moreover, an early detection of lymphoma onset. One of the current diagnostic approaches is the detection of anti-Ro/SSA and/or anti-La/SSB in serum; studies from different groups have demonstrated the presence of these autoantibodies in the saliva of SS patients [111,112]. The determination of salivary autoantibodies seemed to be effective in discriminating SS patients from patients affected by systemic lupus erythematosus (SLE) [113]. A few studies have investigated cytokine profiles in SS saliva; data from these studies showed significantly higher levels of Th1, Th2, and Th17, in accordance with serum findings [114,115]. The proteomic approach in SS comprises proteins, enzymes, calcium-binding proteins, and immune-related molecules. Summarizing, data from the literature report high levels of inflammatory-phase proteins in saliva that can provide a great indication of gland status [116]. Lee et al. 
recently published the results of determination of soluble sialic-acid-binding immunoglobulin-like lectin (siglec)-5 in saliva and sera by ELISA [117]. The level of salivary siglec-5 was significantly higher in the saliva from SS patients, which reflects the severity of hyposalivation. Several novel miRNAs have been described in SS [118]. Pauley et al. demonstrated that the expression of miR-146a was significantly increased in SS patients [119]. In Alevizos' research, another two miRNAs, miR-768-3p and miR-574, were associated with minor salivary gland inflammation in 15 patients with SS [120]. The pathogenesis of autoimmune diseases is a very complex interaction of many factors; epigenetic modifications are now considered crucial to the control of gene expression associated with these diseases [121,122]. Thabet et al. proposed that the dysfunction of salivary gland epithelial cells in SS might be partially linked to epigenetic modifications. Their analysis showed that blood global DNA methylation was reduced in SS patients and the expression of the gene DNMT1, which encodes DNA methyltransferase 1, was decreased compared to healthy controls. In contrast, the expression of the gene Gadd45a, which encodes the growth arrest and DNA-damage-inducible protein GADD45 alpha (GADD45a), was increased [123]. Probably the most interesting field in saliva and SS is the early diagnosis and prevention of MALT-type lymphoma [124]. The neoplasm has an insidious onset, almost asymptomatic, with a fast progression and dissemination. Cui et al. described a triad of markers (anti-cofillin-1, anti-alpha-enolase, and anti-Rho GDP-dissociation inhibitor 2) overexpressed in patients with SS who developed MALT lymphoma compared with SS patients and healthy individuals [125]. Sharma et al. recently examined the role of the microbiome in SS compared to healthy controls [126]. The analysis, performed with DNA isolation and 16rRNA sequencing, revealed four genera (Bifidobacterium, Dialister, Lactobacillus, and Leptotrichia) that were different between the two groups. The results were consistent with previous studies, revealing a role of Actinobacteria and Firmicutes phila [127,128]. More interestingly, Sharma et al. identified a difference in alpha diversity in patients treated with steroids, suggesting the potential role of microbiome analysis in therapeutic response.

\subsection{Psoriasis}

Psoriasis is now classified as an immune-mediated inflammatory disease (IMID) of the skin. It is being recognized that patients with psoriasis are at higher risk of developing systemic co-morbidities, e.g., metabolic syndrome and cardiovascular diseases $[129,130]$.

Oral involvement in course of psoriasis is still debated. Recently, it has been hypothesized that gingivitis and periodontitis share the same underlying inflammatory pathogenic process as psoriasis. Thus, in our previous study, psoriatic patients were investigated for oral mucosa lesion prevalence as well as gum disease. Results displayed an increased association between gingivitis/periodontitis and psoriasis, which may suggest common underlying pathogenic risk factors [131].

Furthermore, salivary secretions, collected from patients with active psoriasis and healthy control subjects, were investigated for expression of interleukin (IL)- $1 \mathrm{~b}$, IL-6, transforming growth factor (TGF)- $\beta 1$, IL-8, tumor necrosis factor (TNF)- $\alpha$, interferon (IFN)- $\chi$, IL-17A, IL-4, IL-10, monocyte chemoattractant protein (MCP)-1, microphage inflammatory protein (MIP)-1a, and MIP-1b using a Multi-Analyte ELISArray Kit (Qiagen, Venlo, the Netherlands). Patients with active psoriasis had significantly higher salivary IL1 $\beta$, TNF- $\alpha$, TGF- $\beta$, and MCP-1 levels than healthy controls [132].

Thus, saliva can be a valid non-invasive tool for monitoring inflammation in psoriasis [133].

\section{Conclusions}

In the era of precision medicine, salivaomics approaches seem to be a promising field of research. Despite encouraging results reported in this review, there is a large variability in study designs, protocols, sampling collections, and techniques. Moreover, the study of new molecules with new technologies requires a well-established range of values without random decisions. Future studies should standardize accurate methodologies in order to validate new salivary biomarkers in clinical practice. 
Author Contributions: E.M. was responsible for the literature revision and drafting; A.C. was responsible for final drafting and revision; F.D. contributed to article analysis; A.O. gave her final revision. All authors have read and agree to the published version of the manuscript.

Funding: This research received no external funding.

Conflicts of Interest: The authors declare no conflict of interest to declare.

\section{References}

1. Qin, R.; Steel, A.; Fazel, N. Oral mucosa biology and salivary biomarkers. Clin. Dermatol. 2017, 35, 477-483. [CrossRef] [PubMed]

2. Holmberg, K.V.; Hoffman, M.P. Anatomy, Biogenesis and Regeneration in Salivary Glands. Monogr. Oral Sci. 2014, 24, 1-13. [PubMed]

3. Mese, H.; Matsuo, R. Salivary secretion, taste and hyposalivation. J. Oral Rehabil. 2007, 34, 711-723. [CrossRef] [PubMed]

4. Kaczor-Urbanowicz, K.E.; Martin Carreras-Presas, C.; Aro, K.; Tu, M.; Garcia-Godoy, F.; Wong, D.T.W. Saliva diagnostics-Current views and directions. Exp. Biol. Med. 2017, 242, 459-472. [CrossRef]

5. Pfaffe, T.; Cooper-White, J.; Beyerlein, P.; Kostner, K.; Punyadeera, C. Diagnostic potential of saliva: Current state and future applications. Clin. Chem. 2011, 57, 675-687. [CrossRef]

6. Javaid, M.A.; Ahmed, A.S.; Durand, R.; Tran, S.D. Saliva as a diagnostic tool for oral and systemic diseases. J. Oral Biol. Craniofacial Res. 2016, 6, 67-76. [CrossRef]

7. Iguiniz, M.; Heinisch, S. Two-dimensional liquid chromatography in pharmaceutical analysis. Instrumental aspects, trends and applications. J. Pharm. Biomed. Anal. 2017, 145, 482-503. [CrossRef]

8. Petti, S. Pooled estimate of world leukoplakia prevalence: A systematic review. Oral Oncol. 2003, 39, 770-780. [CrossRef]

9. Delli, K.; Villa, A.; Farah, C.S.; Celentano, A.; Ojeda, D.; Peterson, D.; Jensen, S.B.; Glurich, I.; Vissink, A. World Workshop on Oral Medicine VII: Biomarkers predicting lymphoma in the salivary glands of patients with Sjögren's syndrome-A systematic review. Oral Dis. 2019, 25, 49-63. [CrossRef]

10. Siqueira, W.L.; Dawes, C. The salivary proteome: Challenges and perspectives. PROTEOMICS Clin. Appl. 2011, 5, 575-579. [CrossRef]

11. Navazesh, M. Methods for Collecting Saliva. Ann. N. Y. Acad. Sci. 1993, 694, 72-77. [CrossRef] [PubMed]

12. Lorenzo-Pouso, A.I.; Pérez-Sayáns, M.; Bravo, S.B.; López-Jornet, P.; García-Vence, M.; Alonso-Sampedro, M.; Carballo, J.; García-García, A.; Zalewska, A. Protein-Based Salivary Profiles as Novel Biomarkers for Oral Diseases. Dis. Markers 2018, 2018, 6141845. [CrossRef] [PubMed]

13. Proctor, G.B.; Carpenter, G.H. Salivary Secretion: Mechanism and Neural Regulation. In Monographs in Oral Science; KARGER: Basel, Switzerland, 2014; Volume 24, pp. 14-29. ISBN 0077-0892.

14. Henson, B.S.; Wong, D.T. Collection, Storage, and Processing of Saliva Samples for Downstream Molecular Applications. In Oral Biology. Methods in Molecular Biology (Methods and Protocols); Humana Press: Totowa, NJ, USA, 2010; Volume 666H.

15. Kaufman, E.; Lamster, I.B. The diagnostic applications of saliva-A review. Crit. Rev. Oral Biol. Med. 2002, 13, 197-212. [CrossRef] [PubMed]

16. Khurshid, Z.; Zohaib, S.; Najeeb, S.; Zafar, M.S.; Slowey, P.D.; Almas, K. Human Saliva Collection Devices for Proteomics: An Update. Int. J. Mol. Sci. 2016, 17, 846. [CrossRef]

17. Schipper, R.; Loof, A.; de Groot, J.; Harthoorn, L.; Dransfield, E.; van Heerde, W. SELDI-TOF-MS of saliva: Methodology and pre-treatment effects. J. Chromatogr. B 2007, 847, 45-53. [CrossRef]

18. Ai, J.; Smith, B.; Wong, D.T. Saliva Ontology: An ontology-based framework for a Salivaomics Knowledge Base. BMC Bioinform. 2010, 11, 302. [CrossRef]

19. Rylander-Rudqvist, T.; Håkansson, N.; Tybring, G.; Wolk, A. Quality and Quantity of Saliva DNA Obtained from the Self-administrated Oragene Method-A Pilot Study on the Cohort of Swedish Men. Cancer Epidemiol. Biomark. Prev. 2006, 15, 1742-1745. [CrossRef]

20. Abraham, J.E.; Maranian, M.J.; Spiteri, I.; Russell, R.; Ingle, S.; Luccarini, C.; Earl, H.M.; Pharoah, P.P.D.; Dunning, A.M.; Caldas, C. Saliva samples are a viable alternative to blood samples as a source of DNA for high throughput genotyping. BMC Med. Genom. 2012, 5, 19. [CrossRef] 
21. Gaździcka, J.; Gołąbek, K.; Strzelczyk, J.K.; Ostrowska, Z. Epigenetic Modifications in Head and Neck Cancer. Biochem. Genet. 2019. [CrossRef]

22. Lee, Y.-H.; Zhou, H.; Reiss, J.K.; Yan, X.; Zhang, L.; Chia, D.; Wong, D.T.W. Direct Saliva Transcriptome Analysis. Clin. Chem. 2011, 57, 1295-1302. [CrossRef]

23. Tutar, Y. Editorial (Thematic Issue: "miRNA and Cancer; Computational and Experimental Approaches"). Curr. Pharm. Biotechnol. 2014, 15, 429. [CrossRef] [PubMed]

24. Kaczor-Urbanowicz, K.E.; Martín Carreras-Presas, C.; Kaczor, T.; Tu, M.; Wei, F.; Garcia-Godoy, F.; Wong, D.T.W. Emerging technologies for salivaomics in cancer detection. J. Cell. Mol. Med. 2017, 21, 640-647. [CrossRef] [PubMed]

25. Prattichizzo, F.; Giuliani, A.; Recchioni, R.; Bonafè, M.; Marcheselli, F.; De Carolis, S.; Campanati, A.; Giuliodori, K.; Rippo, M.R.; Brugè, F.; et al. Anti-TNF- $\alpha$ treatment modulates SASP and SASP-related microRNAs in endothelial cells and in circulating angiogenic cells. Oncotarget 2016, 7, 11945-11958. [CrossRef] [PubMed]

26. Majem, B.; Rigau, M.; Reventós, J.; Wong, D.T. Non-coding RNAs in saliva: Emerging biomarkers for molecular diagnostics. Int. J. Mol. Sci. 2015, 16, 8676-8698. [CrossRef]

27. Bartel, D.P. MicroRNAs: Target recognition and regulatory functions. Cell 2009, 136, 215-233. [CrossRef]

28. Adams, B.D.; Kasinski, A.L.; Slack, F.J. Aberrant regulation and function of microRNAs in cancer. Curr. Biol. 2014, 24, R762-R776. [CrossRef]

29. Bessonneau, V.; Bojko, B.; Pawliszyn, J. Analysis of human saliva metabolome by direct immersion solid-phase microextraction LC and benchtop orbitrap MS. Bioanalysis 2013, 5, 783-792. [CrossRef]

30. Sugimoto, M.; Wong, D.T.; Hirayama, A.; Soga, T.; Tomita, M. Capillary electrophoresis mass spectrometry-based saliva metabolomics identified oral, breast and pancreatic cancer-specific profiles. Metabolomics 2010, 6, 78-95. [CrossRef]

31. Mikkonen, J.J.W.; Singh, S.P.; Akhi, R.; Salo, T.; Lappalainen, R.; González-Arriagada, W.A.; Lopes, M.A.; Kullaa, A.M.; Myllymaa, S. Potential role of nuclear magnetic resonance spectroscopy to identify salivary metabolite alterations in patients with head and neck cancer. Oncol. Lett. 2018, 16, 6795-6800. [CrossRef]

32. Emwas, A.-H.M. The Strengths and Weaknesses of NMR Spectroscopy and Mass Spectrometry with Particular Focus on Metabolomics Research. In Metabonomics: Methods and Protocols; Bjerrum, J.T., Ed.; Springer: New York, NY, USA, 2015; pp. 161-193. ISBN 978-1-4939-2377-9.

33. McBride, E.M.; Lawrence, R.J.; McGee, K.; Mach, P.M.; Demond, P.S.; Busch, M.W.; Ramsay, J.W.; Hussey, E.K.; Glaros, T; Dhummakupt, E.S. Rapid liquid chromatography tandem mass spectrometry method for targeted quantitation of human performance metabolites in saliva. J. Chromatogr. A 2019, 1601, 205-213. [CrossRef]

34. Beale, D.J.; Jones, O.A.H.; Karpe, A.V.; Dayalan, S.; Oh, D.Y.; Kouremenos, K.A.; Ahmed, W.; Palombo, E.A. A review of analytical techniques and their application in disease diagnosis in breathomics and salivaomics research. Int. J. Mol. Sci. 2017, 18, 24. [CrossRef] [PubMed]

35. Esteves, C.V.; de Campos, W.G.; de Souza, M.M.; Lourenço, S.V.; Siqueira, W.L.; Lemos-Júnior, C.A. Diagnostic potential of saliva proteome analysis: A review and guide to clinical practice. Braz. Oral Res. 2019, 33. [CrossRef] [PubMed]

36. Xiao, H.; Wong, D.T.W. Method development for proteome stabilization in human saliva. Anal. Chim. Acta 2012, 722, 63-69. [CrossRef] [PubMed]

37. Mishra, S.; Saadat, D.; Kwon, O.; Lee, Y.; Choi, W.S.; Kim, J.H.; Yeo, W.H. Recent advances in salivary cancer diagnostics enabled by biosensors and bioelectronics. Biosens. Bioelectron. 2016, 81, 181-197. [CrossRef]

38. Kondo, T. Cancer biomarker development and two-dimensional difference gel electrophoresis (2D-DIGE). Biochim. Biophys. Acta Proteins Proteom. 2019, 1867, 2-8. [CrossRef]

39. Zhang, Y.; Li, X.; Di, Y.P. Fast and Efficient Measurement of Clinical and Biological Samples Using Immunoassay-Based Multiplexing Systems. In Molecular Toxicology Protocols; Keohavong, P., Singh, K.P., Gao, W., Eds.; Springer: New York, NY, USA, 2020; pp. 129-147. ISBN 978-1-0716-0223-2.

40. Lin, A. V Direct ELISA. In ELISA: Methods and Protocols; Hnasko, R., Ed.; Springer: New York, NY, USA, 2015; pp. 61-67. ISBN 978-1-4939-2742-5.

41. Zaura, E.; Brandt, B.W.; Prodan, A.; Teixeira de Mattos, M.J.; Imangaliyev, S.; Kool, J.; Buijs, M.J.; Jagers, F.L.; Hennequin-Hoenderdos, N.L.; Slot, D.E.; et al. On the ecosystemic network of saliva in healthy young adults. ISME J. 2017, 11, 1218-1231. [CrossRef] 
42. Ge, X.; Rodriguez, R.; Trinh, M.; Gunsolley, J.; Xu, P. Oral microbiome of deep and shallow dental pockets in chronic periodontitis. PLoS ONE 2013, 8, e65520. [CrossRef]

43. Burne, R.A.; Zeng, L.; Ahn, S.J.; Palmer, S.R.; Liu, Y.; Lefebure, T.; Stanhope, M.J.; Nascimento, M.M. Progress dissecting the oral microbiome in caries and health. Adv. Dent. Res. 2012, 24, 77-80. [CrossRef]

44. Schwabe, R.F.; Jobin, C. The microbiome and cancer. Nat. Rev. Cancer 2013, 13, 800-812. [CrossRef]

45. Torres, P.J.; Fletcher, E.M.; Gibbons, S.M.; Bouvet, M.; Doran, K.S.; Kelley, S.T. Characterization of the salivary microbiome in patients with pancreatic cancer. PeerJ 2015, 3, e1373. [CrossRef]

46. Buszewski, B.; Rogowska, A.; Pomastowski, P.; Złoch, M.; Railean-Plugaru, V. Identification of microorganisms by modern analytical techniques. J. AOAC Int. 2017, 100, 1607-1623. [CrossRef]

47. Rashid, H.; Lamberts, A.; Diercks, G.F.H.; Pas, H.H.; Meijer, J.M.; Bolling, M.C.; Horváth, B. Oral Lesions in Autoimmune Bullous Diseases: An Overview of Clinical Characteristics and Diagnostic Algorithm. Am. J. Clin. Dermatol. 2019, 20, 847-861. [CrossRef] [PubMed]

48. Jonsson, R.; Brokstad, K.A.; Jonsson, M.V.; Delaleu, N.; Skarstein, K. Current concepts on Sjögren's syndrome-classification criteria and biomarkers. Eur. J. Oral Sci. 2018, 126, 37-48. [CrossRef] [PubMed]

49. Warnakulasuriya, S. Oral potentially malignant disorders: A comprehensive review on clinical aspects and management. Oral Oncol. 2020, 102, 104550. [CrossRef] [PubMed]

50. McCartan, B.E.; Healy, C.M. The reported prevalence of oral lichen planus: A review and critique. J. Oral Pathol. Med. 2008, 37, 447-453. [CrossRef] [PubMed]

51. Thorn, J.J.; Holmstrup, P.; Rindum, J.P.J. Course of various clinical forms of oral lichen planus. A prospective follow-up study of 611 patients. J. Oral Pathol. 1988, 17, 213-218. [CrossRef] [PubMed]

52. Campanati, A.; Brandozzi, G.; Giangiacomi, M.; Simonetti, O.; Marconi, B.; Offidani, A.M. Lichen striatus in adults and pimecrolimus: Open, off-label clinical study. Int. J. Dermatol. 2008, 47, 732-736. [CrossRef]

53. Cheng, Y.-S.L.; Gould, A.; Kurago, Z.; Fantasia, J.; Muller, S. Diagnosis of oral lichen planus: A position paper of the American Academy of Oral and Maxillofacial Pathology. Oral Surg. Oral Med. Oral Pathol. Oral Radiol. 2016, 122, 332-354. [CrossRef]

54. Buajeeb, W.; Okuma, N.; Thanakun, S.; Laothumthut, T. Direct Immunofluorescence in Oral Lichen Planus. J. Clin. Diagn. Res. 2015, 9, ZC34-ZC37. [CrossRef]

55. Lodi, G.; Scully, C.; Carrozzo, M.; Griffiths, M.; Sugerman, P.B.; Thongprasom, K. Current controversies in oral lichen planus: Report of an international consensus meeting. Part 1. Viral infections and etiopathogenesis. Oral Surg. Oral Med. Oral Pathol. Oral Radiol. 2005, 100, 40-51. [CrossRef]

56. Van der Meij, E.H.; Schepman, K.-P.; van der Waal, I. The possible premalignant character of oral lichen planus and oral lichenoid lesions: A prospective study. Oral Surg. Oral Med. Oral Pathol. Oral Radiol. 2003, 96, 164-171. [CrossRef]

57. Radwan-Oczko, M.; Zwyrtek, E.; Owczarek, J.E.; Szcześniak, D. Psychopathological profile and quality of life of patients with oral lichen planus. J. Appl. Oral Sci. 2018, 26, e20170146. [CrossRef] [PubMed]

58. Talungchit, S.; Buajeeb, W.; Lerdtripop, C.; Surarit, R.; Chairatvit, K.; Roytrakul, S.; Kobayashi, H.; Izumi, Y.; Khovidhunkit, S.-o.P. Putative salivary protein biomarkers for the diagnosis of oral lichen planus: A case-control study. BMC Oral Health 2018, 18, 42. [CrossRef] [PubMed]

59. Souza, M.M.; Florezi, G.P.; Nico, M.M.S.; de Paula, F.; Paula, F.M.; Lourenço, S.V. Salivary proteomics in lichen planus: A relationship with pathogenesis? Oral Dis. 2018, 24, 784-792. [CrossRef]

60. De Carvalho, G.C.; Domingues, R.; de Sousa Nogueira, M.A.; Branco, A.C.C.; Manfrere, K.C.G.; Pereira, N.V.; Aoki, V.; Sotto, M.N.; da Silva Duarte, A.J.; Sato, M.N. Up-regulation of Proinflammatory Genes and Cytokines Induced by S100A8 in CD8 + T Cells in Lichen Planus. Acta Derm. Venereol. 2016, 96, 485-489. [CrossRef]

61. Severo, J.S.; Morais, J.B.S.; Beserra, J.B.; dos Santos, L.R.; de Sousa Melo, S.R.; de Sousa, G.S.; de Matos Neto, E.M.; Henriques, G.S.; do Nascimento Marreiro, D. Role of Zinc in Zinc- $\alpha 2$-Glycoprotein Metabolism in Obesity: A Review of Literature. Biol. Trace Elem. Res. 2020, 193, 81-88. [CrossRef]

62. Darczuk, D.; Krzysciak, W.; Vyhouskaya, P.; Kesek, B.; Galecka-Wanatowicz, D.; Lipska, W.; Kaczmarzyk, T.; Gluch-Lutwin, M.; Mordyl, B.; Chomyszyn-Gajewska, M. Salivary oxidative status in patients with oral lichen planus. J. Physiol. Pharmacol. 2016, 67, 885-894.

63. Abdolsamadi, H.; Rafieian, N.; Goodarzi, M.T.; Feradmal, J.; Davoodi, P.; Jazayeri, M.; Taghavi, Z.; Hoseyni, S.-M.; Ahmadi-Motamayel, F. Levels of salivary antioxidant vitamins and lipid peroxidation in patients with oral lichen planus and healthy individuals. Chonnam Med. J. 2014, 50, 58-62. [CrossRef] 
64. Rivarola de Gutierrez, E.; Di Fabio, A.; Salomón, S.; Lanfranchi, H. Topical treatment of oral lichen planus with anthocyanins. Med. Oral Patol. Oral Cir. Bucal 2014, 19, e459-e466. [CrossRef]

65. Skrinjar, I.; Vidranski, V.; Brzak, B.L.; Juras, D.V.; Rogulj, A.A.; Brailo, V.; Boras, V.V. Salivary cortisol levels in patients with oral lichen planus-A pilot case-control study. Dent. J. 2019, 7, 59. [CrossRef]

66. Mansourian, A.; Najafi, S.; Nojoumi, N.; Parhami, P.M.M. Salivary Cortisol and Salivary Flow Rate in Clinical Types of Oral Lichen Planus. Skinmed 2018, 16, 19-22. [PubMed]

67. Lopez-Jornet, P.; Zavattaro, E.; Mozaffari, H.R.; Ramezani, M.; Sadeghi, M. Evaluation of the salivary level of cortisol in patients with oral lichen planus: A meta-analysis. Medicina 2019, 55, 213. [CrossRef] [PubMed]

68. Nadendla, L.K.; Meduri, V.; Paramkusam, G.; Pachava, K.R. Association of salivary cortisol and anxiety levels in lichen planus patients. J. Clin. Diagn. Res. 2014, 8, ZC01. [CrossRef] [PubMed]

69. Rödström, P.-O.; Jontell, M.; Hakeberg, M.; Berggren, U.; Lindstedt, G. Erosive oral lichen planus and salivary cortisol. J. Oral Pathol. Med. 2001, 30, 257-263. [CrossRef] [PubMed]

70. Koray, M.; Dülger, O.; Ak, G.; Horasanli, S.; Üçok, A.; Tanyeri, H.; Badur, S. The evaluation of anxiety and salivary cortisol levels in patients with oral lichen planus. Oral Dis. 2003, 9, 298-301. [CrossRef]

71. Stojanovich, L. Stress and autoimmunity. Autoimmun. Rev. 2010, 9, A271-A276. [CrossRef] [PubMed]

72. Wei, W.; Sun, Q.; Deng, Y.; Wang, Y.; Du, G.; Song, C.; Li, C.; Zhu, M.; Chen, G.; Tang, G. Mixed and inhomogeneous expression profile of Th1/Th2 related cytokines detected by cytometric bead array in the saliva of patients with oral lichen planus. Oral Surg. Oral Med. Oral Pathol. Oral Radiol. 2018, 126, 142-151. [CrossRef]

73. Hodge, D.R.; Peng, B.; Cherry, J.C.; Hurt, E.M.; Fox, S.D.; Kelley, J.A.; Munroe, D.J.; Farrar, W.L. Interleukin 6 Supports the Maintenance of p53 Tumor Suppressor Gene Promoter Methylation. Cancer Res. 2005, 65, 4673-4682. [CrossRef]

74. Mozaffari, H.R.; Sharifi, R.; Sadeghi, M. Interleukin-6 levels in the serum and saliva of patients with oral lichen planus compared with healthy controls: A meta-analysis study. Cent. Eur. J. Immunol. 2018, 43, 103-108. [CrossRef]

75. Baggiolini, M.; Clark-Lewis, I. Interleukin-8, a chemotactic and inflammatory cytokine. FEBS Lett. 1992, 307, 97-101. [CrossRef]

76. Mozaffari, H.R.; Sharifi, R.; Mirbahari, S.; Montazerian, S.; Sadeghi, M.; Rostami, S. A systematic review and meta-analysis study of salivary and serum interleukin-8 levels in oral lichen planus. Postep. Dermatol. Alergol. 2018, 35, 599-604. [CrossRef] [PubMed]

77. Rhodus, N.L.; Cheng, B.; Myers, S.; Miller, L.; Ho, V.; Ondrey, F. The feasibility of monitoring NF- $\mathrm{BB}$ associated cytokines: TNF- $\alpha$, IL- $1 \alpha$, IL-6, and IL- 8 in whole saliva for the malignant transformation of oral lichen planus. Mol. Carcinog. 2005, 44, 77-82. [CrossRef] [PubMed]

78. Rhodus, N.L.; Cheng, B.; Bowles, W.; Myers, S.; Miller, L.; Ondrey, F. Proinflammatory cytokine levels in saliva before and after treatment of (erosive) oral lichen planus with dexamethasone. Oral Dis. 2006, 12, 112-116. [CrossRef] [PubMed]

79. Warnakulasuriya, S. Global epidemiology of oral and oropharyngeal cancer. Oral Oncol. 2009, 45, 309-316. [CrossRef] [PubMed]

80. Mehrtash, H.; Duncan, K.; Parascandola, M.; David, A.; Gritz, E.R.; Gupta, P.C.; Mehrotra, R.; Amer Nordin, A.S.; Pearlman, P.C.; Warnakulasuriya, S.; et al. Defining a global research and policy agenda for betel quid and areca nut. Lancet Oncol. 2017, 18, e767-e775. [CrossRef]

81. Yete, S.; D'Souza, W.; Saranath, D. High-Risk Human Papillomavirus in Oral Cancer: Clinical Implications. Oncology 2018, 94, 133-141. [CrossRef]

82. Scheifele, C.; Reichart, P.A. Is there a natural limit of the transformation rate of oral leukoplakia? Oral Oncol. 2003, 39, 470-475. [CrossRef]

83. Offidani, A.; Simonetti, O.; Bernardini, M.L.; Alpagut, A.; Cellini, A.; Bossi, G. General Practitioners' Accuracy in Diagnosing Skin Cancers. Dermatology 2002, 205, 127-130. [CrossRef]

84. Mignogna, M.D.; Fedele, S.; Russo, L.L.; Ruoppo, E.; Muzio, L.L. Oral and pharyngeal cancer: Lack of prevention and early detection by health care providers. Eur. J. Cancer Prev. 2001, 10, 381-383. [CrossRef]

85. Mehdipour, M.; Shahidi, M.; Manifar, S.; Jafari, S.; Mashhadi Abbas, F.; Barati, M.; Mortazavi, H.; Shirkhoda, M.; Farzanegan, A.; Elmi Rankohi, Z. Diagnostic and prognostic relevance of salivary microRNA-21, -125a, -31 and -200a levels in patients with oral lichen planus-A short report. Cell. Oncol. 2018, 41, 329-334. [CrossRef] 
86. Park, N.J.; Zhou, H.; Elashoff, D.; Henson, B.S.; Kastratovic, D.A.; Abemayor, E.; Wong, D.T. Salivary microRNA: Discovery, characterization, and clinical utility for oral cancer detection. Clin. Cancer Res. 2009, 15, 5473-5477. [CrossRef]

87. Sun, Y.-M.; Lin, K.-Y.; Chen, Y.-Q. Diverse functions of miR-125 family in different cell contexts. J. Hematol. Oncol. 2013, 6, 6. [CrossRef] [PubMed]

88. Ishikawa, S.; Sugimoto, M.; Edamatsu, K.; Sugano, A.; Kitabatake, K.; Iino, M. Discrimination of oral squamous cell carcinoma from oral lichen planus by salivary metabolomics. Oral Dis. 2020, 26, 35-42. [CrossRef] [PubMed]

89. Ma, B.; Simala-Grant, J.L.; Taylor, D.E. Fucosylation in prokaryotes and eukaryotes. Glycobiology 2006, 16, 158R-184R. [CrossRef] [PubMed]

90. Miyoshi, E.; Moriwaki, K.; Nakagawa, T. Biological Function of Fucosylation in Cancer Biology. J. Biochem. 2008, 143, 725-729. [CrossRef] [PubMed]

91. Sanjay, P.; Hallikeri, K.; Shivashankara, A. Evaluation of salivary sialic acid, total protein, and total sugar in oral cancer: A preliminary report. Indian J. Dent. Res. 2008, 19, 288-291. [PubMed]

92. Dhakar, N.; Astekar, M.; Jain, M.; Saawarn, S.; Saawarn, N. Total sialic acid, total protein and total sugar levels in serum and saliva of oral squamous cell carcinoma patients: A case control study. Dent. Res. J. 2013, 10, 343-347.

93. Dadhich, M.; Prabhu, V.; Pai, V.; D'Souza, J.; Harish, S.; Jose, M. Serum and salivary sialic acid as a biomarker in oral potentially malignant disorders and oral cancer. Indian J. Cancer 2014, 51, 214-218.

94. Panda, M.; Rai, A.K.; Rahman, T.; Das, A.; Das, R.; Sarma, A.; Kataki, A.C.; Chattopadhyay, I. Alterations of salivary microbial community associated with oropharyngeal and hypopharyngeal squamous cell carcinoma patients. Arch. Microbiol. 2019. [CrossRef]

95. Healy, C.M.; Moran, G.P. The microbiome and oral cancer: More questions than answers. Oral Oncol. 2019, 89, 30-33. [CrossRef]

96. Marttila, E.; Uittamo, J.; Rusanen, P.; Lindqvist, C.; Salaspuro, M.; Rautemaa, R. Acetaldehyde production and microbial colonization in oral squamous cell carcinoma and oral lichenoid disease. Oral Surg. Oral Med. Oral Pathol. Oral Radiol. 2013, 116, 61-68. [CrossRef]

97. Marttila, E.; Uittamo, J.; Rusanen, P.; Lindqvist, C.; Salaspuro, M.; Rautemaa, R. Site-specific acetaldehyde production and microbial colonization in relation to oral squamous cell carcinoma and oral lichenoid disease. Oral Surg. Oral Med. Oral Pathol. Oral Radiol. 2015, 119, 697-699. [CrossRef] [PubMed]

98. Alnuaimi, A.D.; Ramdzan, A.N.; Wiesenfeld, D.; O’Brien-Simpson, N.M.; Kolev, S.D.; Reynolds, E.C.; McCullough, M.J. Candida virulence and ethanol-derived acetaldehyde production in oral cancer and non-cancer subjects. Oral Dis. 2016, 22, 805-814. [CrossRef] [PubMed]

99. Moritani, K.; Takeshita, T.; Shibata, Y.; Ninomiya, T.; Kiyohara, Y.; Yamashita, Y. Acetaldehyde production by major oral microbes. Oral Dis. 2015, 21, 748-754. [CrossRef] [PubMed]

100. Wu, J.; Peters, B.A.; Dominianni, C.; Zhang, Y.; Pei, Z.; Yang, L.; Ma, Y.; Purdue, M.P.; Jacobs, E.J.; Gapstur, S.M.; et al. Cigarette smoking and the oral microbiome in a large study of American adults. ISME J. 2016, 10, 2435-2446. [CrossRef] [PubMed]

101. Corbaux, C.; Joly, P. Bullous Diseases. In Current Problems in Dermatology; KARGER: Basel, Switzerland, 2017; Volume 53, pp. 64-69. ISBN 1421-5721.

102. Murrell, D.F.; Peña, S.; Joly, P.; Marinovic, B.; Hashimoto, T.; Diaz, L.A.; Sinha, A.A.; Payne, A.S.; Daneshpazhooh, M.; Eming, R.; et al. Diagnosis and Management of Pemphigus: Recommendations by an International Panel of Experts. J. Am. Acad. Dermatol. 2019. [CrossRef] [PubMed]

103. Andreadis, D.; Lorenzini, G.; Drakoulakos, D.; Belazi, M.; Mihailidou, E.; Velkos, G.; Mourellou-Tsatsou, O.; Antoniades, D. Detection of pemphigus desmoglein 1 and desmoglein 3 autoantibodies and pemphigoid BP180 autoantibodies in saliva and comparison with serum values. Eur. J. Oral Sci. 2006, 114, 374-380. [CrossRef]

104. Ali, S.; Kelly, C.; Challacombe, S.J.; Donaldson, A.N.A.; Bhogal, B.S.; Setterfield, J.F. Serum and salivary IgG and IgA antibodies to desmoglein 3 in mucosal pemphigus vulgaris. Br. J. Dermatol. 2016, 175, $113-121$. [CrossRef]

105. Hallaji, Z.; Mortazavi, H.; Lajevardi, V.; Tamizifar, B.; Amirzargar, A.; Daneshpazhooh, M.; Chams-Davatchi, C. Serum and salivary desmoglein 1 and 3 enzyme-linked immunosorbent assay in pemphigus vulgaris: Correlation with phenotype and severity. J. Eur. Acad. Dermatology Venereol. 2010, 24, 275-280. [CrossRef] 
106. De, D.; Khullar, G.; Handa, S.; Joshi, N.; Saikia, B.; Minz, R.W. Correlation between salivary and serum anti-desmoglein 1 and 3 antibody titres using ELISA and between anti-desmoglein levels and disease severity in pemphigus vulgaris. Clin. Exp. Dermatol. 2017, 42, 648-650. [CrossRef]

107. Russo, I.; Saponeri, A.; Michelotto, A.; Alaibac, M. Salivary samples for the diagnosis of Pemphigus vulgaris using the BIOCHIP approach: A pilot study. In Vivo 2017, 31, 97-100. [CrossRef] [PubMed]

108. Brito-Zerón, P.; Baldini, C.; Bootsma, H.; Bowman, S.J.; Jonsson, R.; Mariette, X.; Sivils, K.; Theander, E.; Tzioufas, A.; Ramos-Casals, M. Sjögren syndrome. Nat. Rev. Dis. Prim. 2016, 2, 16047. [CrossRef] [PubMed]

109. Pasoto, S.G.; Adriano de Oliveira Martins, V.; Bonfa, E. Sjögren's syndrome and systemic lupus erythematosus: Links and risks. Open Access Rheumatol. Res. Rev. 2019, 11, 33-45.

110. Fernández-Martínez, G.; Zamora-Legoff, V.; Hernández Molina, G. Oral health-related quality of life in primary Sjögren's syndrome. Reumatol. Clínica (Engl. Ed.) 2019. [CrossRef]

111. Ben-Chetrit, E.; Fischel, R.; Rubinow, A. Anti-SSA/Ro and anti-SSB/La antibodies in serum and saliva of patients with Sjogren's syndrome. Clin Rheumatol. 1993, 12, 471-474. [CrossRef] [PubMed]

112. Ching, K.H.; Burbelo, P.D.; Gonzalez-Begne, M.; Roberts, M.E.P.; Coca, A.; Sanz, I.; Iadarola, M.J. Salivary anti-Ro60 and anti-Ro52 antibody profiles to diagnose Sjogren's Syndrome. J. Dent. Res. 2011, 90, 445-449. [CrossRef]

113. Hu, S.; Vissink, A.; Arellano, M.; Roozendaal, C.; Zhou, H.; Kallenberg, C.G.M.; Wong, D.T. Identification of autoantibody biomarkers for primary Sjögren's syndrome using protein microarrays. Proteomics 2011, 11, 1499-1507. [CrossRef]

114. Ohyama, K.; Moriyama, M.; Hayashida, J.-N.; Tanaka, A.; Maehara, T.; Ieda, S.; Furukawa, S.; Ohta, M.; Imabayashi, Y.; Nakamura, S. Saliva as a potential tool for diagnosis of dry mouth including Sjögren's syndrome. Oral Dis. 2015, 21, 224-231. [CrossRef]

115. Kang, E.H.; Lee, Y.J.; Hyon, J.Y.; Yun, P.Y.; Song, Y.W. Salivary cytokine profiles in primary Sjögren's syndrome differ from those in non-Sjögren sicca in terms of TNF- $\alpha$ levels and Th-1/Th-2 ratios. Clin. Exp. Rheumatol. 2011, 29, 970-976.

116. Katsiougiannis, S.; Wong, D.T.W. The Proteomics of Saliva in Sjögren's Syndrome. Rheum. Dis. Clin. N. Am. 2016, 42, 449-456. [CrossRef]

117. Lee, J.; Lee, J.; Baek, S.; Koh, J.H.; Kim, J.-W.; Kim, S.-Y.; Chung, S.-H.; Choi, S.S.; Cho, M.-L.; Kwok, S.-K.; et al. Soluble siglec-5 is a novel salivary biomarker for primary Sjogren's syndrome. J. Autoimmun. 2019, 100, 114-119. [CrossRef]

118. Tandon, M.; Gallo, A.; Jang, S.-I.; Illei, G.G.; Alevizos, I. Deep sequencing of short RNAs reveals novel microRNAs in minor salivary glands of patients with Sjögren's syndrome. Oral Dis. 2012, 18, 127-131. [CrossRef] [PubMed]

119. Pauley, K.M.; Stewart, C.M.; Gauna, A.E.; Dupre, L.C.; Kuklani, R.; Chan, A.L.; Pauley, B.A.; Reeves, W.H.; Chan, E.K.L.; Cha, S. Altered miR-146a expression in Sjögren's syndrome and its functional role in innate immunity. Eur. J. Immunol. 2011, 41, 2029-2039. [CrossRef] [PubMed]

120. Alevizos, I.; Alexander, S.; Turner, R.J.; Illei, G.G. MicroRNA expression profiles as biomarkers of minor salivary gland inflammation and dysfunction in Sjögren's syndrome. Arthritis Rheum. 2011, 63, 535-544. [CrossRef] [PubMed]

121. Ibáñez-Cabellos, J.S.; Seco-Cervera, M.; Osca-Verdegal, R.; Pallardó, F.V.; García-Giménez, J.L. Epigenetic Regulation in the Pathogenesis of Sjögren Syndrome and Rheumatoid Arthritis. Front. Genet. 2019, 10, 1104. [CrossRef]

122. Konsta, O.D.; Thabet, Y.; Le Dantec, C.; Brooks, W.H.; Tzioufas, A.G.; Pers, J.O.; Renaudineau, Y. The contribution of epigenetics in Sjogren's Syndrome. Front. Genet. 2014, 5, 71. [CrossRef] [PubMed]

123. Thabet, Y.; Le Dantec, C.; Ghedira, I.; Devauchelle, V.; Cornec, D.; Pers, J.-O.; Renaudineau, Y. Epigenetic dysregulation in salivary glands from patients with primary Sjögren's syndrome may be ascribed to infiltrating B cells. J. Autoimmun. 2013, 41, 175-181. [CrossRef]

124. Baldini, C.; Giusti, L.; Ciregia, F.; Da Valle, Y.; Giacomelli, C.; Donadio, E.; Ferro, F.; Galimberti, S.; Donati, V.; Bazzichi, L.; et al. Correspondence between salivary proteomic pattern and clinical course in primary Sjögren syndrome and non-Hodgkin's lymphoma: A case report. J. Transl. Med. 2011, 9, 188. [CrossRef]

125. Cui, L.; Elzakra, N.; Xu, S.; Xiao, G.G.; Yang, Y.; Hu, S. Investigation of three potential autoantibodies in Sjogren's syndrome and associated MALT lymphoma. Oncotarget 2017, 8, 30039-30049. 
126. Sharma, D.; Sandhya, P.; Vellarikkal, S.K.; Surin, A.K.; Jayarajan, R.; Verma, A.; Kumar, A.; Ravi, R.; Danda, D.; Sivasubbu, S.; et al. Saliva microbiome in primary Sjögren's syndrome reveals distinct set of disease-associated microbes. Oral Dis. 2019. [CrossRef]

127. Siddiqui, H.; Chen, T.; Aliko, A.; Mydel, P.M.; Jonsson, R.; Olsen, I. Microbiological and bioinformatics analysis of primary Sjögren's syndrome patients with normal salivation. J. Oral Microbiol. 2016, 8, 31119. [CrossRef]

128. Li, B.; Selmi, C.; Tang, R.; Gershwin, M.E.; Ma, X. The microbiome and autoimmunity: A paradigm from the gut-liver axis. Cell. Mol. Immunol. 2018, 15, 595-609. [CrossRef] [PubMed]

129. Campanati, A.; Ganzetti, G.; Giuliodori, K.; Marra, M.; Bonfigli, A.; Testa, R.; Offidani, A. Serum levels of adipocytokines in psoriasis patients receiving tumor necrosis factor- $\alpha$ inhibitors: results of a retrospective analysis. Int. J. Dermatol. 2015, 54, 39-45. [CrossRef] [PubMed]

130. Campanati, A.; Ganzetti, G.; Giuliodori, K.; Postacchini, V.; Liberati, G.; Azzaretto, L.; Vichi, S.; Guanciarossa, F.; Offidani, A. Homocysteine plasma levels in psoriasis patients: our experience and review of the literature. J. Eur. Acad. Dermatol. Venereol. 2015, 29, 1781-1785.

131. Ganzetti, G.; Campanati, A.; Santarelli, A.; Pozzi, V.; Molinelli, E.; Minnetti, I.; Brisigotti, V.; Procaccini, M.; Emanuelli, M.; Offidani, A.; et al. Periodontal disease: an oral manifestation of psoriasis or an occasional finding? Drug Dev. Res. 2014, 75, S56-S59.

132. Ganzetti, G.; Campanati, A.; Santarelli, A.; Pozzi, V.; Molinelli, E.; Minnetti, I.; Brisigotti, V.; Procaccini, M.; Emanuelli, M.; Offidani, A. Involvement of the oral cavity in psoriasis: Results of a clinical study. Br. J. Dermatol. 2015, 172, 282-285. [CrossRef] [PubMed]

133. Ganzetti, G.; Campanati, A.; Santarelli, A.; Sartini, D.; Molinelli, E.; Brisigotti, V.; Di Ruscio, G.; Bobyr, I.; Emanuelli, M.; Offidani, A. Salivary interleukin-1 $\beta$ : Oral inflammatory biomarker in patients with psoriasis. J. Int. Med. Res. 2016, 44, 10-14. [CrossRef]

(C) 2020 by the authors. Licensee MDPI, Basel, Switzerland. This article is an open access article distributed under the terms and conditions of the Creative Commons Attribution (CC BY) license (http://creativecommons.org/licenses/by/4.0/). 